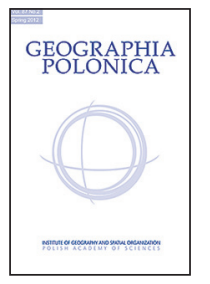

\title{
LAND ACQUISITION AND LAND VALUE CAPTURE INSTRUMENTS AS DETERMINANTS OF PUBLIC URBAN INFRASTRUCTURE PROVISION: A COMPARISON OF THE POLISH LEGAL FRAMEWORK WITH ITS GERMAN COUNTERPART
}

\section{Tomasz Zaborowski}

Faculty of Geography and Regional Studies University of Warsaw Krakowskie Przedmieście 30, 00-927 Warsaw: Poland e-mail: t.zaborowski@uw.edu.pl

\begin{abstract}
Prior to the approval of the Urban Regeneration Act 2015 (UR 2015) the Polish land management system did not provide sufficient quantity and quality of public urban infrastructure. Along with land-use planning, inefficient land acquisition and land value capture frameworks may be blamed for this situation. This paper aims at estimating the extent of progressive change of the Polish law amendments made by the UR act by applying a benchmark of relevant German legal regulations. Identified changes have developed the Polish toolkit of urban infrastructure provision, but effective and comprehensive frameworks of land readjustment and infrastructure-based betterment levies are still missing.
\end{abstract}

\section{Key words}

land management - planning framework - land-use planning - land value capture - Poland - Germany $\bullet$ urban infrastructure

\section{Introduction}

Prior to the legislative amendment of the Polish land-use planning and land management system by the 2015 Urban Regeneration Act (ustawa o rewitalizacji - UR) 1 it did not pro-

\footnotetext{
${ }^{1}$ Complete list of abbreviations used in the paper can be found at the end of the article.
}

vide sufficient quantity and quality of urban infrastructure. In effect a considerable share of land-use patterns that emerged in Poland in the last 25 years are deprived of some elements of urban infrastructure, e.g. decent streets and public spaces (Kowalewski et al. 2014). The core reason for this phenomenon seems to be a poor institutional framework for the provision of public urban infrastructure, 
which is a part of an ineffective planning and land management system (Jędraszko 2005). Ineffective planning and land management resulted in an over-supply of development land which therefore is impossible to urbanize

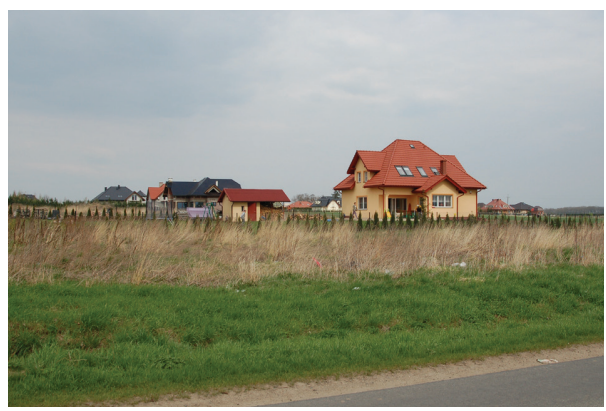

Figure 1. Unplanned growth produces settlement patterns deprived of public urban infrastructure. Outskirts of Wrocław, Poland

in a correct manner (Kowalewski et al. 2014; Zaborowski 2015) (Fig. 1).

On the 9th of October 2015 the Urban Regeneration Act (UR 2015) was passed by the Polish Parliament. Its main aim was to provide planning and economic instruments to carry out effective urban regeneration of the most deprived urban areas. As public infrastructure is one of the core aspects of quality urban space, a question arises: did the UR 2015 act improve the previous, ineffective legal framework of public urban infrastructure (PUI) provision? To provide a benchmark for the amended Polish planning and land management framework, its German counterpart has been analyzed.

In its principles Polish planning was modelled on the Prussian and Austrian systems that had been used in parts of the country before 1918 (Jędraszko 2005). Therefore the German and Polish planning frameworks share similar features, e.g. the principle of communal sovereignty, a two-stage system of local plans, and the possibility to build up land not covered by binding development plans (Niewiadomski 2009; Hansson 2017). However, the German legal framework has evolved over years according to changing challenges to remain an effective system of providing well-organized urban patterns, well equipped with quality public infrastructure.

Germany is regarded as one of the leaders in controlling land use (Halleux et al. 2012). In contrast to Poland, it attained a spatial planning system effectively integrated with socioeconomic (Ścibor 2007) and investment planning (Izdebski et al. 2007). A cornerstone of the latter integration are developer obligations, whose introduction was perceived as a "marked shift from strategic to projectbased development planning" (Hansson 2017: 472; Dieterich 2009).

Common legal features of both planning systems enable a relatively easy transfer of institutional solutions, that therefore are discussed in the literature (Jędraszko 2005; Billert 2007; Bryx \& Jadach-Sepioło 2009). Nevertheless, various transferability obstacles (Dolowitz \& Medearis 2009) may hinder an effective policy emulation (Halleux et al. 2012). Therefore described tools should be regarded as "potential institutions" to be indigenized (Djelic 2010: 26).

The research question of this article is if, and to what extent, the discussed amendments to the Polish legal framework result in convergence with its German counterpart in terms of legal tools of public urban infrastructure (PUI) provision? To answer this question several research steps have been taken. Firstly, the legal framework of PUI provision has been conceptualized. Then, detailed regulations of the three legal frameworks - the Polish one prior and posterior to the 2015 UR amendments, as well as German one, have been identified. By applying a benchmark of respective German regulations, the extent of progressive change of the amended Polish legal framework has been estimated. Finally, some recommendations of desirable further amendments have been formulated. In addition, the suggested modifications were compared with two official legislative reform proposals, that if enacted, would further change the legal framework of public urban infrastructure provision. 
The conducted institutional analysis is limited to legal institutions. Although discussion of detailed transferability problems remains out of scope of this paper (cp. Rye et al. 2011), possible system-wide constraints have been identified. The main investigated enactments encompass two versions of the Polish planning (UPZP) and land management (UGN) acts, anterior (UGN 2015; UPZP 2015) and posterior (UGN 2016; UPZP 2016) to the amendments made by the Urban Regeneration Act (UR 2015). Their German counterpart is the comprehensive Development Code (BauGB 2004). The new Polish act proposals are: s.c. investment act (UI 2017) and Urban \& Development Code (KUB 2017). The first proposal would amend i.a. the Polish planning framework. The latter, if enacted, would replace current planning, land management and building laws in a similar way to its German counterpart (BauGB).

The material scope of this paper is limited to the adopted definition of the public urban infrastructure (PUI). It encompasses all publically owned, both technical and social amenities that service adjacent buildings and sites (cp. Kirwan 1989). Provision of PUI is discussed only in connection with ordinary land development process.

\section{Conceptual framework}

All regulatory instruments of PUI provision can be divided into direct and indirect instruments (Fig. 2). The direct instruments are directly related to PUI provision, whereas the indirect instruments may serve to acquire the necessary land or money to provide PUI. Among direct instruments of PUI provision a general legal requirement to provide relevant PUI along with land development seems to have a crucial meaning. Other approaches encompass infrastructure-based betterment levies (Alterman 2012; Walters 2012) as well as different kinds of developer obligations to supply or finance PUI in exchange for obtaining or enhancing development rights. A special toolkit of comprehensive infrastructure provision along with the acquisition of necessary land or money is land readjustment (Larsson 1997; Muñoz Gielen 2014).

Developer obligations can be either mandatory or voluntary (cp. Heeres et al. 2016). In the first case they are a condition of granting a planning or development permit, whereas in the second one they are an optional requirement to relax development conditions (cp. Kirwan 1989). The mandatory developer obligations are either negotiable or nonnegotiable (Alterman 2012; Muñoz Gielen 2010). Eligible scope of developer obligations cover the whole process of PUI provision, i.e. the initial supply of necessary land and money as well as the direct development of infrastructure. Depending on the scope of developer obligations they may be considered either direct or indirect tools of PUI provision. The indirect ones serve to acquire land or money necessary to provide public urban infrastructure (PUI).

Assembling land to supply the variety of public needs is a problem shared by local governments across the world (Alterman 2007). Among the tools of land acquisition, pre-emption and expropriation (Muñoz Gielen 2010) are internationally recognized approaches of land assembly. In addition to them public easement enables the use of land for a public purpose, but without owning its freehold.

Along with an infrastructure-based betterment levy, municipalities may use indirect tools to collect money necessary for PUI supply. Among them development rights based betterment levies (Wyatt 2016) as well as different types of land-value taxes (Walters 2012; Kirwan 1989) can be applied. Landvalue taxes are regarded as having the ability to play a positive role in urban development, encompassing building on vacant sites equipped with PUI (Foldvary 2008).

All the identified tools of PUI provision, except the purely normative legal regulations and the operational land assembly instruments, may be considered land value capture (LVC) instruments (Ingram \& Hong 2012; cp. Muñoz Gielen 2014). The reverse of LVC is 
INSTRUMENTS OF PUBLIC URBAN INFRASTRUCTURE (PUI) PROVISION

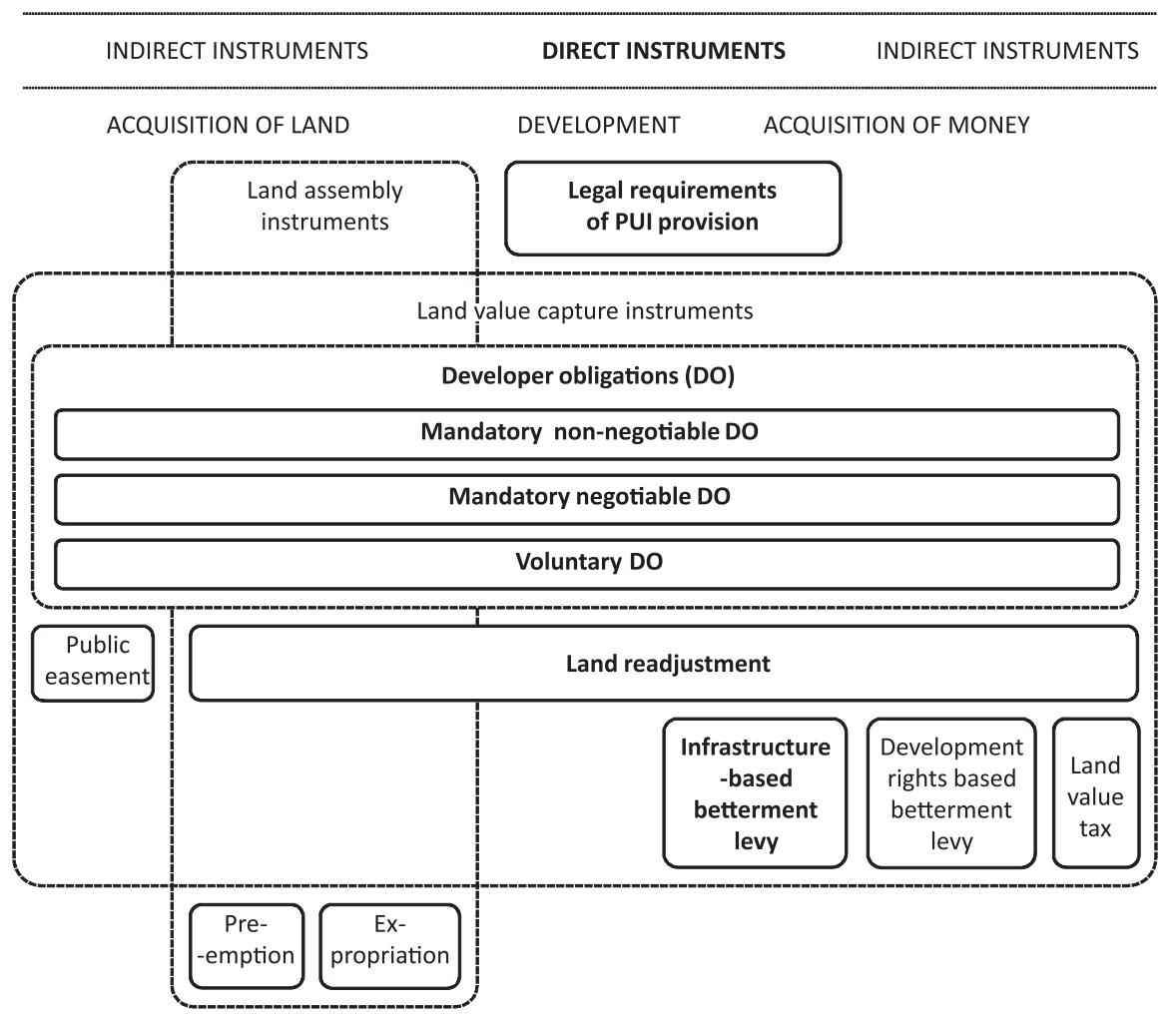

Figure 2. Legal framework of public urban infrastructure (PUI) provision

public obligation to compensate for a loss of property value due to compulsory takeover of various property rights (Shapiro 2012; Alterman 2012). The level of compensation payable by public authorities may be regarded as a stimulus or a hindrance to undertake land management activities, inevitable to supply PUI.

Distinguished instruments form a legal framework of public urban infrastructure (PUI) provision that has been used to identify and compare regulations specific to each of the investigated legal frameworks (Fig. 2). The identified individual instruments may be part of complex tool sets, called Integrated Programs or Complex Urban Programs (Calabrò \& Della Spina 2014). Such bundles, because of possible synergic effects, are important complements to the basic set of planning instruments ${ }^{2}$. However, due to their composite character, they remain out of the scope of this paper.

\section{Analysis}

\section{The Polish legal framework of public urban infrastructure provision prior to the 2015 law amendments}

Direct instruments for public urban infrastructure provision

In the analyzed Polish planning framework there is ${ }^{3}$ not any obligatory link between land

2 There are interesting examples of such complex tools in the German special urban development law (besonderes Städtebaurecht) formulated in the Development Code (BauGB 136-191).

3 The present tense is used to indicate that respec- 
development and provision of PUI (Nelicki \& Zachariasz 2008). In case of ordinary land development, there are two legal bases to get a development permit in Poland: the legally binding local development plan (miejscowy plan zagospodarowania przestrzennego MPZP) and auxiliary planning permit (decyzja o warunkach zabudowy i zagospodarowania terenu - DWZ) ${ }^{4}$, that may be issued in areas that are not covered by binding plans (MPZP).

Municipalities are not bound to build the PUI that they have designated in local development plans. "For, the local development plan defines land use, not an obligation to implement specified investment" ${ }^{5}$. Thus, in accordance with a resolution of the Highest Administrative Court, "there is no right to claim construction of a defined road, deriving from the general municipal duty to construct roads" 6 . However, there is such a legal commitment in the case of a land readjustment resolution (UGN 2015, 106.3).

In theory neighbouring buildings, an access to a public road and technical infrastructure, as well as conformity with agricultural and forest land protection rules are required to get the auxiliary planning permit (DWZ) (UPZP 2015, 61.1). In practice, due to weak legal requirements or permissive judicial interpretation of the law, issuing these ad hoc decisions for developments without an access to a paved road, sewage system, public amenities, and located on greenfield land not adjoining a built up plot is regularly approved (Izdebski et al. 2007). Technical infrastructure may be existing or only planned. The access to public road has to be neither direct nor

tive provisions are still in force.

4 There are two types of such ad hoc planning decisions: a private purpose decision on development conditions and a public purpose decision on location of a public purpose development.

5 Sentence of the regional administrative court (WSA) in Poznań from 4 October 2017 (IV SA/Po 447/17); see also: Sentence of the regional administrative court (WSA) in Poznań from 4 August 2016 (II SA/ Po 306/16).

${ }^{6}$ Resolution of the Highest Administrative Court (NSA) from 9 April 2014 (I OSK 771/14). paved $^{7}$. According to administrative courts, "the term access to the public road ought to be perceived as widely as possible" ${ }^{\text {. }}$. The only official link between development of land and the provision of PUI is stipulated outside of the main planning framework, in the Public Roads Act (UDP 2015). Developers are obliged to (re)construct necessary public roads resulting from their non-road investment (UDP 2015, 16.1). The conditions and scope of this contribution is to be agreed upon a contract between the investor and the road's administrator (UDP 2015, 16.2). Consequently, it may be regarded as a mandatory negotiable developer obligation.

Pursuant to the UGN $(2015,144.1)$ act, landowners participate in development costs of technical infrastructure by the payment of an infrastructure-based betterment levy. Nevertheless, some limitations diminish its scope. Firstly, the levy does not include soft infrastructure, like greenery, parks, public squares, schools etc., leaving all respective financial burden to municipalities. The second limitation is its voluntary character (UGN 2015, 145.1). Many municipalities are reluctant to charge their citizens with infrastructure-based betterment levies (NIK 2003, 2007). The next weaknesses are the allowable level of the levy and the way it is determined. Its maximum level is $50 \%$ of the real property value increase related to the public investment (UGN 2015, 146.1). It means that the levy is not related to the real investment costs but with related property value increase. Accordingly, it may not be collected until the relevant infrastructure is completed (UGN 2015, 145.1), which means that the authorities cannot use the levy to finance the investment directly. In conclusion, the described infrastructure-based betterment levy system

\footnotetext{
7 Sentence of the regional administrative court (WSA) in Poznań from 19 October 2016 (IV SA/Po 44/16).

8 Sentence of the regional administrative court (WSA) in Rzeszów from 4 September 2013 (II SA/Rz 282/13); see also: Sentence of the regional administrative court (WSA) in Warsaw from 29 November 2009 r. (IV SA/Wa 1433/09).
} 
is regarded as expensive, complicated and ineffective (Nelicki \& Zachariasz 2008).

Prior to the 2015 amendments the only mandatory developer obligation envisaged by the public law was the agreement mentioned above on the extent of costs of public road (re)construction to be covered by the developer (UDP 2015, 16). Because of the lack of secondary legislation, this theoretically mandatory, non-negotiable instrument, essentially turns out to be negotiable. Additionally, this regulation is rarely executed as a tool of PUI provision, and only by large investments. It remains theoretical in cases of the most typical small investments, such as single family housing (Fig. 3). The most common application scope of this law is limited to financing private access to the public road network. However, this narrow interpretation of the article 16 of the UDP is not supported by jurisprudence, that proves the right to use this provision to finance construction of public roads 9 .

In the analyzed planning framework there are not any regulations allowing co-financing of local development plans (MPZP) or voluntary developer obligations (cp. Havel 2014). The UPZP $(2015,52.3,64)$ expresses explicitly a ban to make granting of the auxiliary planning permit (DWZ) conditional on anything not foreseen by the legal regulations. According to administrative courts, such a conditioning is illegal also in case of the local development plan, that must not make development conditional to any uncertain acting of public bodies $^{10}$.

In line with the UGN act $(2015,102)$ local authorities may order land readjustment (scalenie i podziat nieruchomości) for areas that have a valid local development plan (MPZP), or upon request of a majority of landowners. However, in the case of a built-up property, its owner's consent is required. As long

\footnotetext{
9 Sentence of the regional administrative court (WSA) in Cracow from 9 January 2014 (II SA/Kr 1226/13).

10 Sentence of the regional administrative court (WSA) in Gorzów Wielkopolski from 11 May 2016 (II SA/Go 189/16).
}

as PUI provision is concerned, only the designation of roads is a precondition for compulsory land takeover (UGN 2015, 105.4). As far as the financial consequences of the process are concerned, there is a strong imbalance between public and private expenditures. Landowners have to pay a betterment levy of a maximum of $50 \%$ of the land value increase related to the land readjustment (UGN 2015, 107.1). On the contrary, the public party has to pay $100 \%$ compensation for land acquired for roads (UGN 2015, 106.1), in compliance with existing expropriation regulations (discussed below). Local authorities may recover procedural costs only if the land readjustment was initiated by landowners (UGN 2015, 103.6). Unfavourable economic conditions of land readjustment discourage Polish municipalities to apply this instrument, therefore it is barely used by them (Jędraszko 2005).

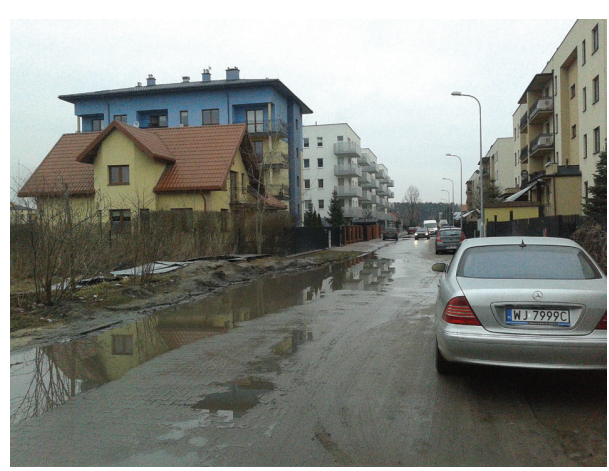

Figure 3. Residential district lacking basic urban infrastructure. Zabki, agglomeration of Warsaw, Poland.

\section{Indirect instruments of public urban infrastructure provision}

The municipality's rights to pre-empt an ordinary real-estate are limited to the properties designated for a public purpose in a legally binding local development plan (MPZP), or its substitute in the form of a decision on location of a public purpose development (UGN $2015,109.3)$. There are not any land-banking 
regulations that could help to collect land to provide PUI in an easier and cheaper way (Nalepka 2012).

According to the Polish constitution (Constitution 1997), any expropriation of realestate is permissible only for a public purpose and with sound compensation. Thus it is limited by the legal definition of public purpose, provided by UGN $(2015,6)$. Prior to the 2015 UR law amendment this definition encompassed collecting land for only some types of infrastructure amenities, excluding some important types of urban public spaces (e.g. squares and green areas). In accordance with public easement regulations, in a local development plan (MPZP) or a decision on location of a public purpose development a local authority can obligate a landowner to allow development of technical infrastructure installations on their property (UGN 2015, 124.1).

The Polish development rights based betterment levy is related to a real-estate value increase resulting from an adoption of a local development plan (MPZP) (UPZP 2015, 36.4). The captured share of the value increase may amount up to $30 \%$ and it must be higher than 0\% (NSA 2006) - so it is obligatory. However, due to several further constraints, this pre-requisite turns out to be rather theoretical. The levy is due only in the case of the disposal of the property, if it takes place no later than five years after the plan adoption (UPZP 2015, 37.3). Landowners deliberately wait to sell their plots until this period has expired. The outlined legal structure of this betterment levy makes it complicated and expensive to collect. As a result many Polish municipalities deliberately give up to exact the levy (Nelicki \& Zachariasz 2008).

There is not any official and universal landvalue taxation system in Poland. The basis of determining a real property tax is the area of land or buildings (UPOL 2014, 4.1). The tax rate may differ depending on the location, and the current or planned use. However, maximum rates are determined by law and they are much lower in the case of land in comparison to buildings (UPOL 2014, 5.1).
Currently, there is not any tool to tax private land relative to its market value. On the contrary, in case of publicly owned land, the government body may lease it in an ordinary way, or use a special form of land lease, called perpetual usufruct (użytkowanie wieczyste). The latter is a specific, long term land lease, with extended property rights granted to the leaseholder (s.c. perpetual user użytkownik wieczysty), who has to pay each year $0,3 \%$ to $3 \%$ of the property market value (UGN 2015, 72.3). The property in both cases belongs to a public body, so the levy cannot be regarded as a LVC instrument. However, as the lease payment is an incentive to develop the land, the result is similar to the application of a land-value tax.

\section{Compensation}

The seemingly most important reason why the analyzed Polish framework of PUI provision is not effective is an imbalance of costs and revenues related to planning and urbanization processes (Stacherzak et al. 2014). According to Olbrysz \& Koziński (2011), in rural municipalities income related to local planning covered only $2,1 \%$ of the involved costs and $0,1 \%$ in cities. The main reason of this imbalance are huge compensation amounts that public authorities are obliged to pay for both planning and land assembly activities (cp. Alterman 2010). Whereas municipalities are allowed to capture only $30 \%$ of land value increase caused by granting development rights, they have to compensate $100 \%$ of the respective land value loss (UPZP 2015, 36.3). As mentioned before, in fact Polish municipalities are not able to capture even the theoretical $30 \%$ share of land value increments. Furthermore, in the case of expropriation, a compensation due equals market value of the real property that includes the value increase caused by the planned public investment (UGN 2015, 134.4). In the discussed system these totally unearned 'windfalls' are not possible to be covered by any 'wipe-outs' (Hagman \& Miszczynski 1978; Stacherzak et al. 2014). 


\section{Polish legal framework of public urban infrastructure provision after the 2015 law amendments}

\section{Direct instruments of public urban infrastructure provision}

As a result of the 2015 law amendments, no new regulations directly conditioning land development on PUI supply came into force. However, the planning framework has been slightly changed in order to assure a better link between development land designations and infrastructure provision. Among the new preconditions to the outline land-use framework (studium uwarunkowań i kierunków zagospodarowania przestrzennego - SUKZP), municipal capability to finance PUI has to be considered (UPZP 2016, 10.1). The total quantity of land designated for development may not exceed a limit derived from this consideration (UPZP 2016, 10.5.6).

In special urban regeneration zones (specjalna strefa rewitalizacji - SSR) ${ }^{11}$, a higher rate of the infrastructure-based betterment levy was introduced. Instead of the ordinary 50\% limit, municipalities may capture up to $75 \%$ of the increments resulting from a public investment in technical infrastructure (UGN 2016, 146.2a).

The Urban Regeneration Act (UR 2015) introduced mandatory non-negotiable developer obligations as a precondition to grant a development permit. In a special type of the local development plan - an urban regeneration local plan (miejscowy plan rewitalizacji - MPR), local authorities may commit a developer to provide PUI foreseen in an urban development contract (umowa urbanistyczna) (UR 2015, 37i).

The new legal framework did not introduce any voluntary developer obligations or mandatory negotiable ones to be imposed

\footnotetext{
11 According to the UR act, a special urban regeneration zone (SSR) may be officially designated by municipality on an urban regeneration area. They are designated to make use of special legal regulations envisaged in the UR act.
}

on developers as a condition to receive a planning (DWZ) or development permit. As land readjustment frameworks are concerned, the UR 2015 (37I.1) act provided some special regulations for officially designated urban regeneration areas (obszar rewitalizacji) ${ }^{12}$. Along with a procedure of making a MPR plan, a land readjustment procedure may be conducted, what should accelerate the latter.

Indirect instruments of public urban infrastructure provision

Pre-emption rights have been extended to all real-estates located in special urban regeneration zones (SSR) (UR 2015, 11.5.1; UGN 2016, 109.1.4a-b). Additionally, the UR act expanded the list of public purpose investments eligible for expropriation for the development of public walkways, parks, squares and promenades (UGN 2016, 6.9c). The expropriation process of real-estates with unclear legal status located in special urban regeneration zones (SSR) has been simplified (UR 2015, 31.1). The analyzed UGN (2016, 124c.1.2) amendment increased possibilities to impose a public easement by provision of public walkways.

The previous legal framework of the development rights based betterment levy (opłata planistyczna) has not been changed. In contrast, local authorities have been granted a land-value taxation tool. In line with UR 2015 (37.2) a municipality has to tax undeveloped plots located on urban regeneration areas (obszar rewitalizacji), designated for mixed-use, housing or commercial development in a local development plan, should the 4-year waiting period have expired.

\section{Compensation}

With the Urban Regeneration Act (UR 2015 , 33.2) the level of pecuniary claim resulting from urban regeneration processes

\footnotetext{
12 An urban regeneration area is an area located on officially designated s.c. degraded area. The latter may cover maximally $20 \%$ of municipal area and $30 \%$ of inhabitants.
} 
in special urban regeneration zones (SSR) is based on the state of the property as of the date of the official adoption of the urban regeneration area. It seems that this regulation (being ius specialis) could derogate the UGN $(2016$, 134.4) provision that requires including in the compensation amount a property value increase created by the prospective public investment (ius generalis). However, judicature on a similar provision of the Special Rules of Public Roads Development Act (USZPRI 2015) ${ }^{13}$ indicates that such a legal interpretation is not presumable ${ }^{14}$.

\section{German legal framework of public urban infrastructure provision}

\section{Direct instruments of public urban infrastructure provision}

In Germany, there is a general legal requirement for PUI provision before the completion of adjacent buildings (BauGB 2015, 123.2). It means that the presence of infrastructure is one of the conditions to receive a building permit (BauGB 2015, 30, 34, 35). Municipality is obliged to provide infrastructure indicated by binding development plans (Bebauungsplan - B-Plan) (Fig. 4).

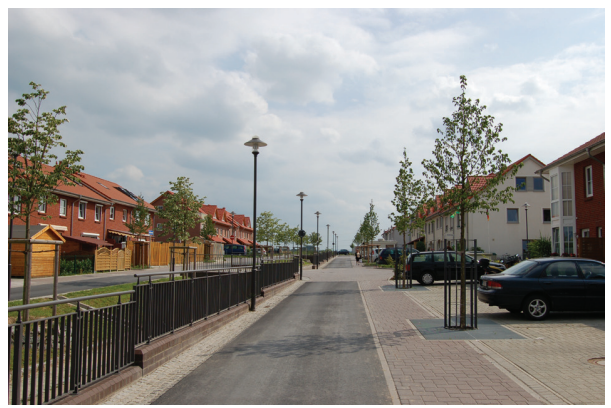

Figure 4. Residential district fully equipped with public urban infrastructure. Seelze Süd, Region Hannover, Germany.

\footnotetext{
${ }^{13}$ Within the current legal framework public bodies may construct roads either on this special enactment or on the general planning act (UPZP).

14 Sentence of the regional administrative court (WSA) in Białystok from 10 November 2016 (II SA/Bk 412/16).
}

German municipalities may collect an infrastructure-based betterment levy (Erschließungsbeitrag) to cover the costs of urban infrastructure, which comprises i.a. adjacent streets and footways, squares, essential collecting roads, car parks and greenery (BauGB 2015, 127). The law allows collecting up to $90 \%$ of development costs that have not been paid from other resources. An additional levy to cover relevant costs of the technical infrastructure may be collected according to provisions of the federal state's enactment (Battis et al. 2007).

In Germany there are no mandatory nonnegotiable nor negotiable developer obligations to provide PUI. In contrary, voluntary developer obligations are widespread. There are two such tools identified in the BauGB 2015 act:

- an urban development contract (städtebaulicher Vertrag) (BauGB 2015, 11),

- a development proposal and linkage plan (Vorhaben- und Erschließungsplan) (BauGB 2015, 12).

Both instruments are mechanisms for enhancing the quality and speeding up the PUI provision, thus accelerating implementation of the development scheme (Nelicki \& Zachariasz 2008). The second instrument additionally provides a way to legitimate a development proposal that would not be otherwise permitted, by including it in a special kind of development plan (vorhabenbezogener Bebauungsplan) under the condition of additional infrastructure provision. The reward for the public party may be broader in the case of the urban development contract, encompassing all possible urban development, land administration and planning activities, i.a. technical and social infrastructure supply (BauGB 2015, 11). In the development proposal and linkage plan a developer commits to pay for related planning costs and complete a development with all the relevant urban infrastructure. Both instruments enable the collection of $100 \%$ of the total costs of the PUI provision (cp. Ziniewicz 2012) and are regarded as successful (Hansson 2017). 
In Germany land readjustment (Umlegung) is a common technique to obtain necessary land and money to supply PUI. However, it is assessed as relatively inefficient (Hartmann \& Spit 2015). It is always carried out by local authorities and does not require any consent of the landowners. Local authorities are allowed to take over up to $30 \%$ of greenfield and $10 \%$ of brownfield land. The value of the taken over land is accounted as part of a $100 \%$ betterment levy that is to be collected from landowners (BauGB 2015, 58). A distinct legal framework of land readjustment is envisaged for areas of extraordinary public intervention that are subject to the special urban development law (besonderes Städtebaurecht). Under this law land readjustment is an obligatory part of the urban development measures (städtebauliche Entwicklungsmaßnahmen) (BauGB 2015, 165; cp. Bryx \& Jadach-Sepioło 2009).

\section{Indirect instruments of public urban infrastructure provision}

The German pre-emption rights (Vorkaufsrecht) may be executed only if it serves the common good, which is not limited to a defined list of public purposes as in the Polish case (BauGB $2015,24.3)$. It aims to assure that real properties are used in conformity with a local development plan (B-Plan), or to implement wellordered urban development (BauGB 2015, 24, 25). All undeveloped plots zoned for housing and all areas located within a development plan may be pre-empted. Likewise, in the case of expropriation (Enteignung), German municipalities can expropriate real-estates not only for public purposes but also to foster private investments aimed at infilling consistently built-up areas or implementation of a development plan (B-Plan) (BauGB 2015, 85.1, 87.3).

The public easement (Baulasten) may be imposed as a condition to grant a development permit (Korbmacher 2005). However, it does not impact the provision of PUI. In Germany, there is not any regular development rights based betterment levy. The special urban development law provides for a com- pensation amount payable by landowners in urban regeneration areas (BauGB 2015, 154.1). It equals increment caused by public activities and replaces normally collected infrastructure-based betterment levy.

In Germany the municipalities are entitled to levy a land value tax (Grunsteuer) (GrStG 2008 , 1). The tax level is subject to municipal decisions, whereas respective base ratios are regulated by federal law (GrStG 2008, $14-15,25)$. The yearly base ratio is $6 \%$ of the standard land value in case of land used for agricultural and forest production purposes (Grundsteuer A), and 3,5\% for developed and developable land ${ }^{15}$ (Grundsteuer B) (GrStG 2008, 15). Municipalities may multiply these base ratios in accordance with the GrStG 200825 provisions. In 2016 the average multiplier factor for Grundsteuer A was 332\%, and for Grundsteuer B 464\% (Statistisches Bundesamt 2017). The result is that the average land tax yearly ratio for ordinary developable and developed plots was 1,62\% of their standard value.

\section{Compensation}

An owner of expropriated property is entitled to public compensation based on the property market value. It encompasses both current and designated use value. However, it is clearly stated, that prospective increments related to the purpose of expropriation are excluded from the account (BauGB 2015, 95.2.2). A compensation resulting from the regulatory taking of land-use rights is to include reclaimed potential value only within a period of seven years (BauGB 2015, 42). According to Alterman (2010: 33) this time limit is "central to the German approach to regulatory takings". To lower potential compensation amount, the municipality may pass s.c. alteration ban (Veränderungssperre) for the area of plan preparation. It interdicts any land development that could cause a significant property value increment (BauGB

\footnotetext{
15 The base ratios for single and two-family housing land are slightly lower.
} 
2015, 14.1). Expropriation law explicitly excludes any such changes from compensation being due (BauGB 2015, 95.2.4). This rule applies also to the pre-emption of real properties that could be subject to expropriation (BauGB 2015, 28).

\section{Conclusions and recommendations}

\section{Conclusions}

On the basis of the undertaken analysis, one can conclude that due to the legislative changes the Polish legal framework of PUI provision has converged to some extent with its German counterpart. The discussed legal amendments provide a little step forward to a "developed mode of urbanisation" (Kirwan 1989: 285) and "active operational planning" (Halleux et al. 2012: 888), that involves provision of relevant infrastructure. Hopefully the Polish planning is regenerating after many years of "institutional inertia" characterized by low levels of adaptiveness and innovativeness (Halleux et al. 2012: 896).

Nevertheless, some concerns may be raised, regarding the scope of progressive change, bearing in mind circumstances that form specific spatial and legal backgrounds. The oversupply of developable land combined with the costly withdrawal of development rights requires further reaching changes in the legal framework. The strong imbalance between public and private property rights is a complex issue that requires comprehensive institutional solutions, not being limited to specific areas. The new introduced voluntary land management instruments may be not sufficient to change the whole land development market, which is dominated by municipalities competing for developers. Municipalities might be reluctant in imposing additional charges and developers will not be likely to invest on areas where such charges will be imposed, if they have plenty of cheaper options.

Based on these conclusions, some recommendations for further legal amendments may be formulated. Some of them have been already included in two addressed govern- mental proposals of acts, that hopefully will further change the analyzed legal framework.

\section{Recommendations}

\section{Public urban infrastructure provision as a condition to receive development permit}

In most cases, new land acquisition and land value capture (LVC) instruments are foreseen to be used only in specially designated urban regeneration areas. Comprehensive, flexible tools for effective, planned (re)urbanization of ordinary areas are still missing. To stop further development of urban patterns deprived of decent PUI, a legal obligation to supply PUI along with the development of buildings should be introduced similarly to the German BauGB 2015 (30, 34, 35) regulations.

The next amendments to the planning framework should change the present requirements of providing key infrastructure along with land development. According to the s.c. investment act a plot to be developed must have access to a public road and technical infrastructure that either exists or is guaranteed in a contract according to the Public Roads Act (UDP 2016, 16.2; UI 2017, 7.20).

Some progressive provisions of infrastructure requirements are comprised in the proposal of the Urban \& Development Code (KUB 2017). According to KUB 2017200.1 the municipality would have 8 years to deliver infrastructure envisaged in a local development plan (MPZP). Every new ordinary development must be connected with a public road through a turnoff or an existing, paved non-public road (KUB 2017, 37). Like in Germany, making use of new buildings would be allowed only after the necessary access to technical infrastructure network has been provided (KUB 2017, 54).

\section{Extension of developer obligations framework}

The introduction of the non-negotiable urban development contract (umowa urbanistyczna) 
to the Polish planning framework is undoubtedly a revolutionary amendment of the LVC system. However, it is foreseen to be applied only for specific cases of urban regeneration programmes. Its German voluntary, negotiable counterpart is applicable to all ordinary planning matters (BauGB 2015, 11). Thus, the introduction of voluntary, negotiable developer obligations as an option to get better planning conditions, would give opportunities for developers to cooperate in an official way with municipalities to provide PUI (cp. Monk \& Crook 2016). Such an approach seems to conform to the UPZP $2016(52.3,64)$ provisions, because it does not imply additional conditions to grant planning permit (DWZ) but to enlarge its potential scope or reduce its potential restrictions.

The legal and spatial scope of urban development contracts should be extended by the planned investment act. In case of s.c. areas of organized development (obszary zorganizowanego inwestowania - OZI) it would be the developer to apply for the contract. Thus it would become a voluntary, negotiable developer obligation. A systemic change of approach to the cooperation between public and private entities in implementing planning policy is described in the project of Urban \& Development Code (KUB). According to KUB 2017, 254.1, the rules and procedure of the cooperation must be stipulated in an urban development contract. The KUB 2017249.1 would qualify present requirements of the Public Roads Act (UDP 2017, 16.2). It explicitly obliges the developer to cover the costs of not only road (re)construction, but the public transport and technical infrastructure as well.

\section{Infrastructure-based betterment levy reform}

The Polish application of the infrastructurebased betterment levy is regarded as a distortion of the canonical approach to this LVC instrument that is a contribution to the real costs of infrastructure provision (Ziniewicz 2012). Therefore linking the infrastructurebased betterment levy with real development costs is recommended. The weakness of the Polish tool in comparison with its German highly effective counterpart (Ziniewicz 2012) arises for at least three additional reasons. Firstly, it is limited to purely technical infrastructure. Secondly, calculating the levy on the basis of land value increments is complicated and vague. Thirdly, the maximum level of $50 \%{ }^{16}$ is low in comparison to the German $90 \%{ }^{17}$ level. Thus, an extension of the scope of infrastructure-based betterment levy to include both technical and social urban infrastructure, as well as increasing its level is recommended. High level of infrastructure-based betterment levy does not have to cause a proportional increase of housing prices, as these relate mainly to the local demand and quantity of existing stock (Harvey \& Jowsey 2004).

The investment act proposal does not include any changes in the framework of the infrastructure-based betterment levy. On the contrary, the proposal of the Urban \& Development Code entails a new instrument, the infrastructure levy (opłata infrastrukturalna). Its application would be restricted to s.c. betterment areas (obszary ulepszenia) precisely indicated in the local development plan (MPZP). This new approach is comprehensive, bearing in mind that an ordinary greenfield development should be permitted according to the new code only upon the provisions of the local development plan. The levy would amount to between 10 and $50 \%$ of the actual development cost excluding connections, and $100 \%$ of the cost of connecting plots to the networks (KUB 2017, 161). This legislative amendment does not propose to extend the scope of the levy by including non-technical urban infrastructure.

\section{Limitation of public expenditures involved with planning and urban development activities}

Polish municipalities are obliged to pay compensations disproportionate to poten-

\footnotetext{
16 Of the land value increase.

17 Of the construction costs.
} 
tial revenue derived from land management activities. Regardless of the constitutional requirement for "just" compensation instead of the "full" one (Alterman 2010), the provision of UGN 2016 (134.4) requires by establishing the amount of compensation to take into account publically caused prospective land value increments. Alternatively, German regulations (BauGB 2015, 95.2.2) may serve as a role model to derogate the discussed provision and clearly exclude publically caused increments from the compensation.

Another way to reduce the imbalance of costs and profits in planning activities may be to limit the right to have the reclaimed development rights compensated. A solution may be drawn upon from the German time limitation of development rights to 7 years (BauGB 2015, 42). However, it is possible in the German LVC system, where there is not any direct development rights based betterment levy, which could be reclaimed in case of withdrawal of development rights. From this reason the introduction of similar time limit in Poland would require the redesign of the betterment levy framework, which is currently regarded as ineffective anyway (Nelicki \& Zachariasz 2008). An easy withdrawal of developments rights is a necessary prerequisite to overcome the oversupply of developable land, which systemically hinders provision of urban infrastructure because of lacking urban economies of scale.

Some of the recommended rules are included in the proposals of the new legislation. According to UI 2017, 67f, in cases where there is a signed urban development contract for organized development areas $(\mathrm{OZI})$ the landowners are not entitled to compensation from decreased property value due to the provisions of a local development plan. The proposal of the Urban \& Development Code excludes development rights as a component of real property rights (KUB $2017,14)$. A decrease in property value resulting from a change in the local development plan would entitle the owner to compensation only if, due to new provisions, the property could not be economically developed and it would be disposed of within 5 years from the date of the plan being adopted (KUB 2017, 280). In addition, like in Germany, the compensation would not be required, if within 7 years the owner did not profit from a right to develop their site (KUB 2017 282).

\section{Establishment of land value taxation}

Following the German example, a land value based property tax should be introduced as a tool of land value capture (LVC) and to provide an economic stimulus to mobilize underutilized urban land (Foldvary 2008). An ad valorem tax is regarded as one of the fairest (Foldvary 2010) and least market-distortive taxes (George 1879) as well as a tool to internalize effects of land-use on environment and society (EEA 2010). Unfortunately, both proposals for legislative amendments do not include any components to implement a land value tax.

\section{Land readjustment framework to be enhanced}

The lack of instruments to take over necessary private land (Havel 2014) may be regarded as one of the main deficiencies of the Polish legal framework of PUI provision. The invalid legal construction of the land readjustment framework discourages municipalities from application of this instrument (Niewiadomski 2009). In contrast, the German regulations provide an incentive to undertake land readjustment activities (Jędraszko 2005). Therefore, the introduction of gratuitous land takeover privilege along with compulsory land readjustment is highly recommended. However, as Polish land-owners have a strong sentiment of possessing all possible property ownership rights, the suggested attempts to limit them may meet strong opposition (Ingram \& Hong 2012; Niewiadomski 2009).

The proposal for the investment act (UI 2017) does not include any changes in this 
matter. On the contrary, the KUB 2017 project provides for an obligatory land-readjustment, called land order (porzadek gruntowy) ${ }^{18}$, that should be undertaken in conjunction with the approval of a local development plan, if the current real property structure does not enable the development to be undertaken in conformity with the local development plan regulations (KUB 2017, 35.2). This instrument would require an immediate take-over of any land necessary for public purpose development (KUB 2017, 169.1). Nevertheless, the landowner would still be entitled to $100 \%$ compensation for land take-over (KUB 2017, 171.1). Taking into account that there is not any betterment charge foreseen in the new legal framework, the municipality would have to contribute at least $50 \%$ of public technical infrastructure cost, and $100 \%$ of other

\footnotetext{
${ }^{18}$ It is a misleading loan translation of German Bodenordnung (land management), a term that encompasses all respective tools similar to land-readjustment (Umlegung).
}

PUI financial burdens, in line with respective infrastructure-based betterment levy regulations. Thus, there is still not any urbanization mechanism proposed or considered, that would be profitable from the municipal point of view.

\section{Acknowledgements}

I acknowledge Prof. David Amborski and Dr. Ewa Kołodziejczyk for helping me to improve the English language of this paper as well as Dr. Demetrio Muñoz Gielen for inspiration, scientific support and encouragement. This work was financially supported by: the Rector of the University of Warsaw, the Department of Development Geography and Spatial Planning (the University of Warsaw) and the University of Warsaw Foundation.

Editors' note: Unless otherwise stated, the sources of tables and figures are the authors', on the basis of their own research.

BAuGB, 2015. The Development Code (Baugesetzbuch in der Fassung der Bekanntmachung vom 23. September 2004, BGBI. I S. 2414, das zuletzt durch Artikel 6 des Gesetzes vom 20. Oktober 2015, BGBI. I S. 1722, geändert worden ist).

BILlert A., 2007. Rewitalizacja i rozwój miast w Polsce - uwarunkowania i scenariusze w świetle doświadczeń europejskich [in:] P. Lorens (ed.). Rewitalizacja miast w Polsce. Pierwsze doświadczenia. Biblioteka Urbanisty, vol. 10, Warszawa: Urbanista.

BryX M., JadACh-SepIOŁo A. (eds.), 2009. Rewitalizacja miast w Niemczech. Kraków: Instytut Rozwoju Miast.

Calabrò F., Della Spina L., 2014. The public-private partnerships in buildings regeneration: A model appraisal of the benefits and for land value capture [in:] Advanced Materials Research, vols. 931-932, pp. 555-559.

Constitution, 1997. Constitution of the Republic of Poland of 2 April 1997 (Konstytucja Rzeczypospolitej Polskiej z dnia 2 kwietnia 1997 (Dz. U. 1997, nr 78, poz. 483, ze zm.), 21.2). 
DJelIC M.-L., 2010. Institutional perspectives Working towards coherence or irreconcilable diversity? [in:] G. Morgan, The Oxford Handbook of Comparative Institutional Analysis. Oxford: OUP, pp. 15-34.

DietericH H., 2009. Paradigmenwechsel im deutschen Städtebaurecht [in:] E. Hepperle, H. Lenk (eds.), Land development strategies. Patterns, risks and responsibilities. Zürich: Vdf Hochschulverlag, pp. 113-117.

Dolowitz D.P., Medearis D., 2009. Considerations of the obstacles and opportunities to formalizing cross-national policy transfer to the United States: A case study of the transfer of urban environmental and planning policies from Germany. Environment and Planning C: Government and Policy, vol. 27, pp. 684-697.

EEA, 2010. Land in Europe: prices, taxes and use patterns. European Environment Agency Technical Report, vol. 4. Copenhagen: EEA.

FoldVARY F.E., 2008. The marginalists who confronted land. American Journal of Economics and Sociology, vol. 67, no. 1, pp. 89-117.

FoldVARY F.E., 2010, The Science of Economics. Santa Clara: Cognella.

George H., 1879. Progress and poverty. Garden City, NY: Doubleday, Page \& Company.

GRSTG, 2008. Grundsteuergesetz (Property Tax Act) vom 7. August 1973 (BGBI. I S. 965), das zuletzt durch Artikel 38 des Gesetzes vom 19. Dezember 2008 (BGBI. I S. 2794) geändert worden ist.

Hagman D.G., MisczYnski D.J. (eds.), 1978. Windfalls for wipeouts: Land value recapture and compensation. Chicago: American Society of Planning Officials.

Halleux J.-M., Marcinczak S., van der Krabbgen E., 2012. The adaptive efficiency of land use planning measured by the control of urban sprawl. The cases of the Netherlands, Belgium and Poland. Land Use Policy, vol. 29, no. 4, pp. 887-898.

HANSSON A.G., 2017. Promoting planning for housing development: What can Sweden learn from Germany? Land Use Policy, vol. 64, pp. 470-478.

Hartmann T., Spit T., 2015. Dilemmas of involvement in land management - Comparing an active (Dutch) and a passive (German) approach. Land Use Policy, vol. 42, pp. 729-737.
Harvey J., Jowsey E., 2004. Urban land economics, New York: Palgrave Macmillan.

Havel M.B., 2014. Delineation of property rights as institutional foundations for urban land markets in transition. Land Use Policy, vol. 38, pp. 615-626.

Heeres N., Lenfering S., Tillema T., Arts J., 2016. Beyond financial value capturing? Interactions between value capturing and cooperation at the interface of road infrastructure and land use planning. Town Planning Review, vol. 87, no. 2, pp. 179-204.

IngRAm G.K., Hong Y., 2012. Land value capture: Types and outcomes [in:] G. K. Ingram, \& Y. Hong (eds.), Value Capture and Land Policies. Cambridge, Mass: Lincoln Institute of Land Policy, pp. 3-19.

Izdebski H., Nelicki A., Zachariasz I., 2007. Zagospodarowanie przestrzenne - polskie prawo na tle standardów demokratycznego państwa prawnego. Warszawa: Ernst\&Young.

JęDRASZKO A., 2005. Zagospodarowanie przestrzenne w Polsce - drogi i bezdroża regulacji ustawowych. Warszawa: Unia Metropolii Polskich.

KIRWAN R.M., 1989. Finance for urban public infrastructure. Urban Studies, vol. 26, no. 3, pp. 285-300.

KORBMACHER A., 2005. Bauordnungsrecht [in:] ARL, Handwörterbuch der Raumordnung. Hannover: Verlag der ARL, pp. 82-84.

Kowalewski A., Mordasiewicz J., Osiatyńsk J., Regulski J., Stępień J., Śleszrýnski P., 2014. Ekonomiczne straty i społeczne koszty niekontrolowanej urbanizacji w Polsce - wybrane fragmenty raportu. Samorzad Terytorialny, vol. 4, pp. 5-21.

KUB, 2017. A proposal of Urban \& Development Code of 23 November 2017 (Projekt z dnia 23 listopada 2017 r. ustawy Kodeks urbanistyczno-budowlany).

LARSSON G., 1997. Land readjustment: A tool for urban development. Habitat international, vol. 21, no. 2, pp. 141-152.

Monk S., CROok T., 2016. International experience [in:] T. Crook, J. Henneberry, \& C. Whitehead, (eds.), Planning Gain. Providing Infrastructure \& Affordable Housing. RICS Research, Wiley Blackwell, pp. 227-268. 
Muñoz Gielen D., 2010. Capturing value increase in urban redevelopment. Leiden: Sidestone Press.

Muñoz Gielen D., 2014. Urban governance, property rights, land readjustment and public value capturing. European Urban \& Regional Studies, vol. 21 no. 1, pp. 60-78.

OlBrysz A., KozIŃSKI J., 2011. Raport o finansowych efektach polskiego systemu gospodarowania przestrzeniq. Proceddings from the conference: Finansowe skutki polskiego systemu planowania przestrzennego, [typescript].

NALEPKA A., 2012. Efekty gospodarowania gminnym zasobem nieruchomości i możliwości ich powiększania. Research Papers of Wrocław University of Economics, vol. 262, pp. 261-276.

Nelicki A., Zachariasz I., 2008. Planowanie przestrzenne a udziat podmiotów prywatnych $w$ budowie infrastruktury publicznej. Rozwiqzania polskie a wybranych krajów UE i USA. Samorząd Terytorialny, vol. 10, pp. 29-41.

Niewiadomski Z. (ed.), 2009. Prawna regulacja procesu inwestycyjno-budowlanego. Uwarunkowania, bariery, perspektywy. Warszawa: LexisNexis.

NIK, 2003. Informacja o wynikach kontroli ustalania $i$ egzekwowania przez gminy opłaty adiacenckiej. 2/2003/P02/151/LOL. Olsztyn: NIK.

NIK, 2007. Informacja o wynikach kontroli ustalania i egzekwowania przez gminy opłaty adiacenckiej oraz opłaty planistycznej w latach 2004-2006 (I pótrocze). 15/2007/P/06/144/ LOL. Olsztyn: NIK.

NSA, 2006. Resolution of the Highest Administrative Court (NSA) from 3 October 2006 (II OSK 1041/06).

Rye T., Welsch J., Plevnik A., de Tommasi R., 2011. First steps towards cross-national transfer inintegrating mobility management and land use planning in the EU and Switzerland. Transport Policy, vol. 18, no. 3, pp. 533-543.

SHAPIRO P., 2012. Takings and givings: The analytics of land value capture and its symmetries with takings compensation? [in:] G. K. Ingram, Y. Hong (eds.), Value Capture and Land Policies, Cambridge, Mass: Lincoln Institute of Land Policy. pp. 41-63.
Stacherzak A., Hetdak M., Kazak J., 2014. Obciazzenia finansowe gmin kosztami realizacji dróg. Prace Naukowe Uniwersytetu Ekonomicznego we Wrocławiu, 331, Problemy rozwoju regionalnego i lokalnego, pp. 201-212.

Statistisches Bundesamt, 2017. Pressemitteilung vom 21. August 2017 - 287/17, www.destatis. de [15 May 2018]

ŚCIBOR K., 2007. Ocena wybranych aspektów polskiego planowania przestrzennego w kontekście ZZOP. Coastline Reports, vol. 8, pp. 212-224.

UDP, 2015. Public Roads Act of 21 March 1985 (Ustawa z dnia 21 marca 1985 r. o drogach publicznych - UDP, tekst jedn., Dz.U. 2015 poz. 460.

UGN. The Land Management Act of 21 August 1997 (Ustawa z dnia 21 sierpnia 1997 r. o gospodarce nieruchomościami).

UGN, 2015. The Land Management Act of 21 August 1997 (Ustawa z dnia 21 sierpnia 1997 r. o gospodarce nieruchomościami, tekst jedn., Dz.U. 2015, poz. 782).

UGN, 2016. The Land Management Act of 21 August 1997 (Ustawa z dnia 21 sierpnia 1997 r. - gospodarce nieruchomościami, tekst jedn., Dz.U. 2016, poz. 2147).

UI, 2017. A proposal of s.c. Investment Act of 14 November 2017 (Projekt $z$ dnia 14 listopada 2017 r. ustawy o zmianie niektórych ustaw w zwiqzzu z uproszczeniem procesu inwestycyjno-budowlanego).

UPOL, 2014. The Local Taxes and Levies Act (Ustawa z dnia 12 stycznia 1991 r. o podatkach i opłatach lokalnych (UPOL), tekst jedn., Dz.U. 2014, poz. 849).

UPZP. The Spatial Planning and Development Act of 27 March 2003 (Ustawa z dnia 27 marca 2003 r. o planowaniu i zagospodarowaniu przestrzennym).

UPZP, 2015. The Spatial Planning and Development Act of 27 March 2003 (Ustawa z dnia 27 marca 2003 r. o planowaniu i zagospodarowaniu przestrzennym, tekst jedn., Dz.U. 2015, poz. 199).

UPZP, 2016. The Spatial Planning and Development Act of 27 March 2003 (Ustawa z dnia 27 marca 2003 r. o planowaniu i zagospodarowaniu przestrzennym, tekst jedn., Dz.U. 2016, poz. 778 ). 
UR, 2015. The Urban Regeneration Act of 9 October 2015 (Ustawa z dnia 9 października 2015 r. o rewitalizacji, Dz. U. 2015, poz. 1777).

USZPRI, 2015. Special Rules of Public Roads Development Act of 10 April 2003 (Ustawa z dnia 10 kwietnia 2003 r. o szczególnych zasadach przygotowania i realizacji inwestycji w zakresie dróg publicznych, Dz.U. 2015 nr 0 poz. 2031, 18.1).

WALTeRS L.C., 2012. To what extent are property-related taxes effective value capture instruments? [in:] G. K. Ingram, Y. Hong. (eds.), Value Capture and Land Policies. Cambridge, Mass: Lincoln Institute of Land Policy, pp. 187-215.

WYATT P., 2016. Experiences of running negotiable and non-negotiable developer contributions side-by-side. Planning Practice \& Research, vol. 32, no. 2, pp. 152-170.

ZABOROWSKI T., 2015. Polityka kształtowania koncentracji osadnictwa. Propozycja konceptualizacji i instrumentalizacji na podstawie polityk przestrzennych Anglii i Niemiec [in:] T. Kudłacz, P. Lityński (eds.), Gospodarowanie przestrzenia miast i regionów: uwarunkowania i kierunki, Studia KPZK PAN, 161.

ZINIEWICZ M.A., 2012. Analiza porównawcza opłat adiacenckich w Republice Federalnej Niemiec, Anglii $i$ Polsce. Studia i Materiały Towarzystwa Naukowego Nieruchomości, vol. 20 no. 4, pp. 51-65.

\section{Following abbreviations are used in the paper:}

BauGB Baugesetzbuch (Development Code)

B-Plan Bebeuungsplan (Local Development Plan)

DWZ decyzjaowarunkach zabudowyizagospodarowania terenu (auxiliary planning permit)

KUB kodeks urbanistyczno-budowlany (Urban \& Development Code)

MP miejscowy plan rewitalizacji (urban regeneration local plan)

MPZP miejscowy plan zagospodarowania przestrzennego (local development plan)

PUI public urban infrastructure

SUKZP studium uwarunkowań i kierunków zagospodarowania przestrzennego (outline land-use framework)

UDP ustawa o drogach publicznych (Public Roads Act)

UGN ustawa o gospodarce nieruchomościami (Land Management Act)

UI ustawa inwestycyjna (s.c. investment act)

UPOL ustawa o podatkach i opłatach lokalnych (Local Taxes and Levies Act)

UPZP ustawa o planowaniu i zagospodarowaniu przestrzennym (Spatial Planning and Development Act)

UR ustawa o rewitalizacji (Urban Regeneration Act) 